\title{
Effect of Clindamycin Therapy on Phagocytic and Oxidative Activity Profiles of Spleen Mononuclear Cells in Babesia rodhaini-infected Mice
}

\author{
Agus WIJAYA ${ }^{1)}$, Retno WULANSARI ${ }^{1)}$, Hitoshi $\mathrm{ANO}^{1)}$ and Susumu MAKIMURA ${ }^{1)^{*}}$ \\ ${ }^{1)}$ Laboratory of Veterinary Internal Medicine, Department of Veterinary Science, Faculty of Agriculture, Miyazaki University, Miyazaki \\ 889-2192, Japan
}

(Received 22 September 2000/Accepted 22 January 2001)

\begin{abstract}
Spleen weight, the number of spleen mononuclear cells, and their phagocytic activity in groups of Babesia rodhaini-infected mice treated with diminazene diaceturate and clindamycin increased significantly in the early stage of treatment, and then decreased in the final stage of treatment to approximately the pre-infection level. The number of F4/80-positive macrophages and their oxidative activity per mean whole-spleen weight also increased significantly during the course of treatment in comparison with the untreated group. The increases in the clindamycin-treated group were more prominent than those in the group treated with diminazene diaceturate, suggesting the effectiveness of clindamycin therapy for murine babesiosis.

KEY WORDS: Babesia rodhaini infection, clindamycin, spleen macrophage function.
\end{abstract}

J. Vet. Med. Sci. 63(5): 563-566, 2001

It is well known that existing drugs for the elimination of Babesia parasites are not effective and have associated side effects. Therefore, the most promising strategy for babesiosis therapy may not be rapid and complete elimination of the parasites from the host, but rather to suppress their proliferation without any side effects. Our previous study suggested that clindamycin (CLM) might be an effective alternative drug for treatment of babesiosis in mice, and induce higher resistance to challenge infection in cured mice [10]. In the present study, we examined the phagocytic activity of spleen mononuclear cells (MNC) and oxidative activity of spleen F4/80-positive macrophages (Mø) that might be involved in the therapeutic effect of CLM or diminazene diaceturate on Babesia rodhaini (B. rodhaini) infection in mice. Some workers have reported that the phagocytic and oxidative function of M $\varnothing$ might play an important role in the host protective mechanism in the murine model of babesiosis [4, 7, 9, 11].

Female BALB/c A Jlc mice (Clea Experimental Animal Supplier Co., Japan) and B. rodhaini (Australian strain) were used in this study. The parasites were maintained by intraperitoneal passage with parasitized erythrocytes (pRBC) through BALB/c A Jlc mice. The infected mice were divided into two groups: treated and untreated. The treated mice were subdivided into three groups. As shown in Fig. 1, group one was administered diminazene diaceturate (Ganazeg ${ }^{\circledR}$, Ciba-Geigy, Japan Limited) subcutaneously at $25 \mathrm{mg} / \mathrm{kgBW} /$ day s.i.d. for 3 days, group two was administered clindamycin phosphate $\left(\right.$ Darracin $^{\circledR}$, Up John Co., Tokyo) through a gastric tube at $100 \mathrm{mg} / \mathrm{kg} \mathrm{BW} /$ day b.i.d. for 7 days, and group three was treated with clindamycin $200 \mathrm{mg} / \mathrm{kg} \mathrm{BW/day} \mathrm{s.i.d.} \mathrm{for} 7$ days. Each group comprised 15 to 20 mice. All the mice were fed commercial

\footnotetext{
* Correspondence to: Makimura, S., Laboratory of Veterinary Internal Medicine, Faculty of Agriculture, Miyazaki University, Miyazaki 889-2192, Japan.
}

mouse chow and supplied with distilled water ad libitum.

Mice were inoculated intraperitoneally with $1 \times 10^{6}$ pRBC. Thin blood smears were prepared with a drop of blood collected from the tip of the tail for monitoring the percentage of parasitemia, which was calculated after Diff Quick staining (Kokusai Shiyaku Co., Kobe, Japan). Opsonized zymosan (Sigma Chemical Co., U.S.A.) was prepared by mixing zymosan A with fresh mouse serum and finally suspended at a concentration of $20 \mathrm{mg} / \mathrm{m} l$ in $0.01 \mathrm{M}$ phosphate-buffered saline, $\mathrm{pH} 7.4$ (PBS). The phagocytized particle suspension (Fluoresbrite PC-Red $2.0 \mu$ microspheres, Poly Science, Inc., U.S.A.) was used for analysis of phagocytic activity, while dihydrorhodamine123 (DHR123, Sigma Chemical Co., U.S.A.) was used for oxidative assay of Mø, which were stimulated with opsonized zymosan. A monoclonal antibody against a Mø surface antigen (F4/80 labeled with Phycoerythrin (PE), Caltag Lab., U.S.A.) was used as the Mø marker.

Group 1: $\Delta \Delta \Delta$

Group 2: $\quad \Delta \Delta \Delta \Delta \Delta \Delta \Delta \quad \Delta \Delta \Delta \Delta \Delta \Delta \Delta$

Group 3: $\quad \Delta \Delta \Delta \Delta \Delta \Delta \Delta$

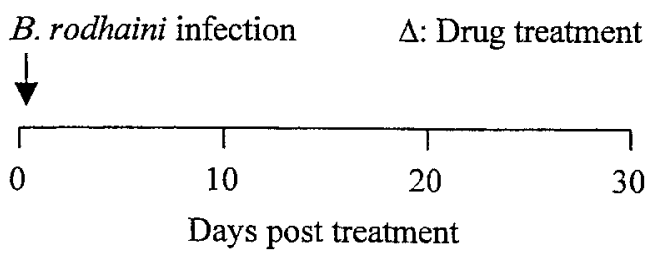

Fig. 1. Treatment time and doses of each drug. Group 1: Diminazene diaceturate $25 \mathrm{mg} / \mathrm{kg}$ BW s.i.d. for 3 days via S.C. route. Group 2: Double treatments of clindamycin (CLM) $100 \mathrm{mg} / \mathrm{kg}$ b.i.d. for 7 days via oral route. Group 3: CLM $200 \mathrm{mg} / \mathrm{kg}$ b.i.d. for 7 days via oral route. Each group was composed of at least 15 to 20 mice. 
To separate the spleen MNC, a spleen cell suspension from four mice was obtained by teasing the excised spleens on a 200-mesh stainless steel sieve in cold Hank's balanced salt solution (HBSS(-)) with EDTA-2K. Spleen MNC were isolated from whole spleen cells by centrifugation over histopaque (1.077, Sigma, St. Louis, MO) and hemolysis using $0.83 \% \mathrm{NH}_{4} \mathrm{Cl}$ solution. The cells were washed in $\mathrm{HBSS}(-)$ at $4^{\circ} \mathrm{C}$ and resuspended at a concentration of $1 \times 10^{7}$ cell $/ \mathrm{m} l$ in $\operatorname{HBSS}(-)$ at $4^{\circ} \mathrm{C}$.

To analyze the spleen MNC phagocytic activity, $1 \mathrm{~m} l$ of MNC suspension containing $1 \times 10^{7}$ cells in a tube was mixed with $10 \mu l$ of phagocytized particle solution (original solution diluted 1:10 with PBS). After incubation of the tube at $37^{\circ} \mathrm{C}$ for $20 \mathrm{~min}$ and then placing it in ice- water for $10 \mathrm{~min}, 1 \mathrm{~m} l$ of cold HBSS (+) was added. The tube was then incubated again at $37^{\circ} \mathrm{C}$ for $20 \mathrm{~min}$, followed by transfer to ice-water for $5 \mathrm{~min}$. The tube was then centrifuged at $400 \times \mathrm{g}$ for $5 \mathrm{~min}$ and the supernatant was removed. Finally, the cells were resuspended in $1 \mathrm{~m} l$ of HBSS(+). Phagocytic activity of the spleen MNC phagocytes was measured using a flow cytometer (EPICS XL, BECKMAN-COULTER, U.S.A.).

To detect the oxidative activity of spleen F4/80-positive $\mathrm{Mø,} 1 \mathrm{~m} l$ of $1 \times 10^{7} \mathrm{MNC} / \mathrm{m} l$ in a tube was mixed with $10 \mu l$ of the original F4/80 solution and kept in ice-water for 30 min. After centrifugation at $400 \times \mathrm{g}$ for $5 \mathrm{~min}$, the supernatant was removed and the pellet cells were mixed with $1 \mathrm{ml}$ of cold HBSS(-) and $2.5 \mu l(5 \mu \mathrm{M})$ of $2 \mathrm{mM}$ DHR123 in dimethylsulfoxide. The tube was further incubated at $37^{\circ} \mathrm{C}$ for $20 \mathrm{~min}$, followed by transfer to ice-water. F4/80-positive M $\varnothing$ and their oxidative activity were measured simultaneously by flow cytometry.

Clearance of parasitemia was observed in all treated mice, whereas untreated mice showed rapid exacerbation of parasitemia in the final stage of infection. The mean hematocrit on the day immediately after treatment in all the treated groups was increased to approximately the pre-infection level, whereas that in the untreated mice decreased rapidly, as shown in Table 1.

The changes in spleen weight, and the number and phagocytic activity of MNC in the infected mice are shown in Fig. 2. The spleen weight of mice in all groups decreased rapidly to approximately the pre-infection level on the day immediately after treatment. In contrast, the spleen weight in untreated mice increased rapidly until the final stage of infection. The number of spleen MNC and their phagocytic activity in the untreated group were significantly greater at 6 days post infection (dpi) than in pre-infected mice. In the treated groups, the number of spleen MNC and their phagocytic activity increased in the early stage of treatment, and then decreased to approximately the pre-infection level in the final stage of the study.

As shown in Fig. 2, spleen F4/80-positive cells in the untreated group increased rapidly up to 17 times the preinfection level by 6 dpi. Spleen F4/80-positive cells in the treated groups were also increased: about 7 -fold in group one by $20 \mathrm{dpi}, 12$-fold in group two by $29 \mathrm{dpi}$, and 27 -fold in group three by $17 \mathrm{dpi}$. All of these increases were significantly higher than those in the untreated group on $6 \mathrm{dpi}$. The oxidative activity in the untreated group increased rapidly up to 17 times the pre-infection level by $6 \mathrm{dpi}$. The oxidative activity in all treated groups also increased significantly during the course of treatment, relative to the untreated group on $6 \mathrm{dpi}$ : the increase was about 3 -fold in group one by $20 \mathrm{dpi}, 11$-fold in group two by $29 \mathrm{dpi}$, and 21 fold in group three by $17 \mathrm{dpi}$.

It has been reported that the oxidative activity of whole spleen $\mathrm{M} \varnothing$ in mice infected with the lethal Plasmodium berghei ( $P$. berghei) is less than that in mice infected with the self-limiting $P$. yoelii. This is due mainly to the considerable increase in the number of Mø in the spleen of mice infected with $P$. yoelii, as compared with $P$. berghei, at 3 dpi [1]. We obtained similar results, i.e. F4/80-positive Mø oxidative activity per whole spleen in treated mice was significantly higher than that in untreated mice.

The M $\varnothing$ oxidative activity in treated mice of group two at 29 dpi was 11-fold greater than that in untreated mice, whereas the activity in treated mice of group one at $20 \mathrm{dpi}$ was only 3-fold higher (Fig. 2). The increased Mø oxidative activity in CLM-treated mice might be associated with the resistance to $B$. rodhaini shown by mice that had recovered after CLM treatment in our previous study [10].

Primary infection with $P$. berghei resulted in increased populations of all spleen white cells and Mø compared with those in normal mice, and the proportions of the different cell populations changed markedly. During chloroquine treatment of infected mice, all spleen cell populations are reported to increase, although their relative proportions remain normal [2]. It has also been reported that the activation and accumulation of F4/80-positive macrophages in the

Table 1. Parasitemia and hematocrit profiles of treated and untreated Babesia rodhaini-infected mice

\begin{tabular}{|c|c|c|c|c|c|c|c|c|c|c|c|c|c|}
\hline & \multirow{2}{*}{\multicolumn{4}{|c|}{ Untreated group ${ }^{\text {a) }}$}} & \multicolumn{9}{|c|}{ Treated groups } \\
\hline & & & & & \multicolumn{3}{|c|}{$\mathrm{DD}^{\mathrm{b})}$} & \multicolumn{3}{|c|}{$\operatorname{CLM}(100-100)^{\mathrm{c})}$} & \multicolumn{3}{|c|}{$\operatorname{CLM}(200)^{\mathrm{d})}$} \\
\hline & $0 \mathrm{dpi}^{\mathrm{e})}$ & 3dpi & $5 \mathrm{dpi}$ & 6dpi & 6dpi & 13dpi & 20dpi & $15 \mathrm{dpi}$ & 29dpi & 38dpi & $11 \mathrm{dpi}$ & $17 \mathrm{dpi}$ & 24dpi \\
\hline Parasitemia (\%) & 0.0 & 0.4 & 3.9 & 37.7 & 0.6 & 0.0 & 0.0 & 0.0 & 0.0 & 0.0 & 0.0 & 0.0 & 0.0 \\
\hline Hematocrit $(\%)$ & 48.5 & 46.0 & 44.0 & 34.4 & 40.9 & 45.9 & 47.3 & 44.8 & 47.5 & 46.8 & 43.5 & 44.9 & 45.8 \\
\hline
\end{tabular}

a) Normal BALB/c A Jcl mice were infected intra-peritoneally with $1 \times 10^{6}$ parasitized RBC. b) Diminazene diaceturate $25 \mathrm{mg} / \mathrm{kg}$ BW s.i.d. for 3 days via S.C. route. c) Double treatments of clindamycin $100 \mathrm{mg} / \mathrm{kg}$ b.i.d. for 7 days via oral route. d) CLM 200 $\mathrm{mg} / \mathrm{kg}$ b.i.d. for 7 days via oral route. e) Days post infection. 
Untreated
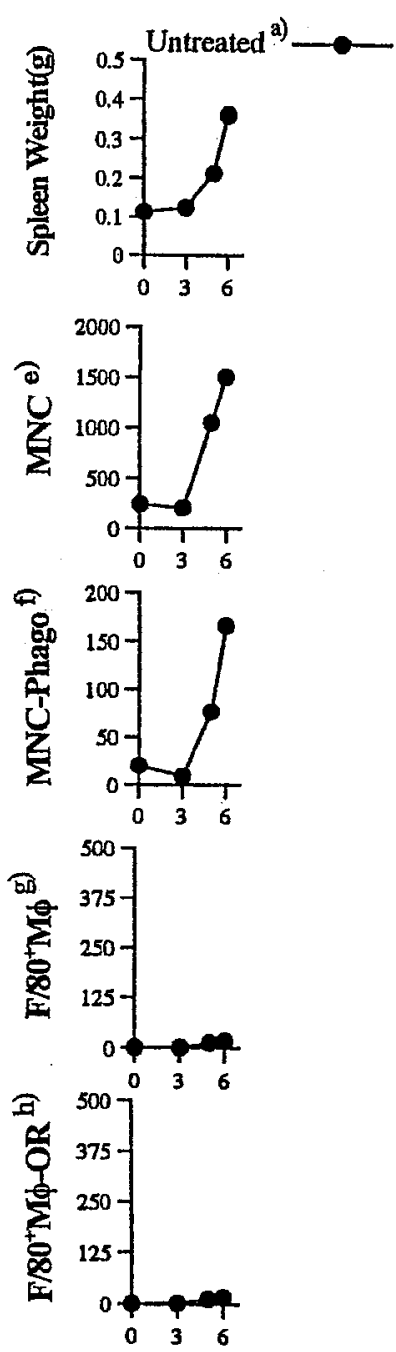

Days Post Infection (DPI)

\section{Treated}
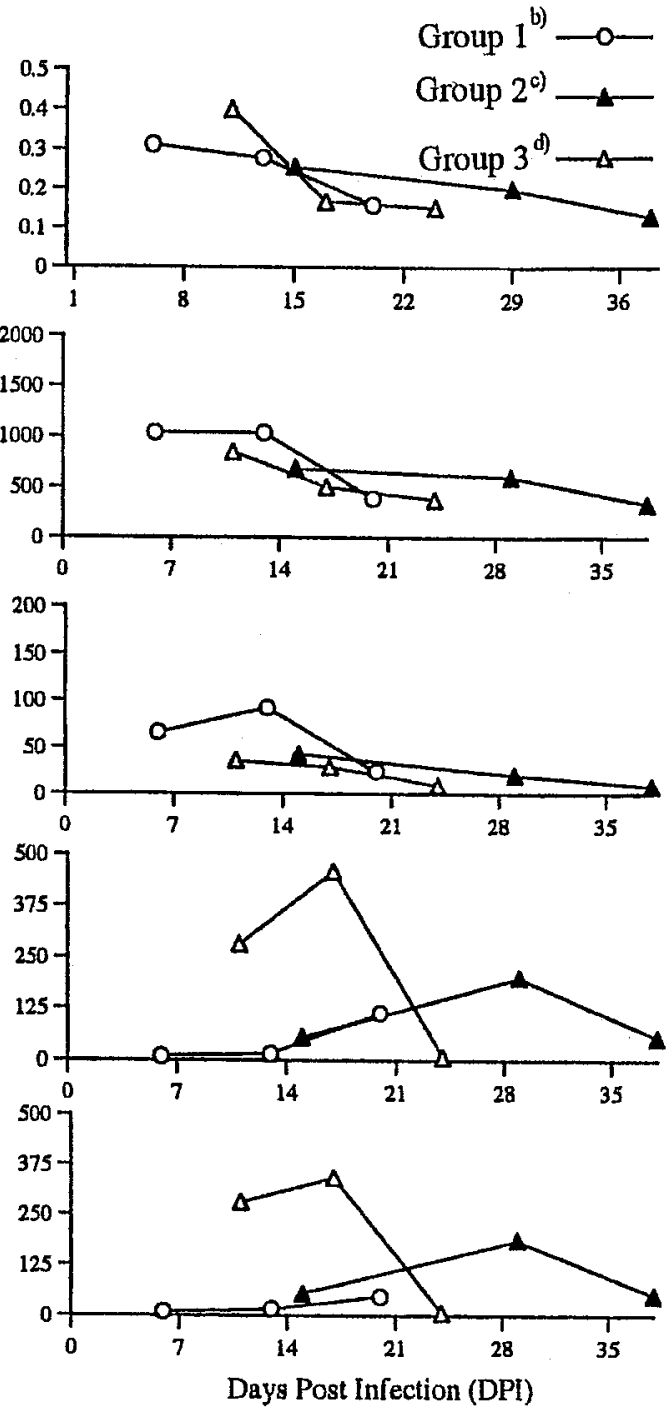

Fig. 2. Profiles of spleen weight, spleen mononuclear cells (MNC), MNC phagocytic activity, spleen $\mathrm{F} 4 / 80^{+}$macrophages (Mø) and $\mathrm{F} 4 / 80^{+} \mathrm{M} \varnothing$ oxidative activity of treated and untreated Babesia rodhaini-infected mice. a) Normal BALB/c A Jcl mice were infected intra-peritoneally with $1 \times 10^{6}$ parasitized RBC. b) Diminazene diaceturate treatment. c) Double treatments of CLM. d) CLM treatment. e) MNC/spleen. f) MNC/spleen phagocyting PC-Red particles. g) A Mø marker, $\mathrm{F} 4 / 80^{+}$cells/spleen. h) Oxygen radical (oxidized dihydrorodamine 123) positive $\mathrm{F} 4 / 80^{+} \mathrm{M} \varnothing /$ spleen which were stimulated with opsonized zymosan.

red pulp of the spleen during murine Plasmodium vinckei infection are associated with gene expression of granulocyte-macrophage colony-stimulating factor (GM-CSF) and IL-1 alpha in the spleen. GM-CSF became detectable as early as 2 days after infection, reached a peak of activity on day 9 , and then rapidly decreased. Therefore, the effect of GM-CSF on activation and accumulation of F4/80-positive macrophages is established at least 4 days after $P$. berghei infection $[5,6]$. In the present study, spleen weight and the number or phagocytic activity of spleen MNC in infected mice declined at $3 \mathrm{dpi}$, and then increased in comparison with the values in pre-infected mice. These results suggest that in the early stage of infection, spleen Mø have yet to accumulate and become activated

Diminazene diaceturate has some side effects, one of which is acute idiopathic polyneuritis (Landry-GuillainBarre syndrome) in human patients with $B$. microti infection [8]. On the other hand, CLM differs chemically from lincomycin in that a chlorine atom is substituted for a hydroxyl group. This substitution allows CLM to be better absorbed, 
thus reducing the incidence of adverse effects [3]. For this reason, CLM may be a safer drug.

In this study we have demonstrated that CLM-treated mice show a significant increase in the number of F4/80positive Mø and the oxidative activity of whole spleen cells in comparison with diminazene diaceturate-treated mice (Fig. 2). Increases in both the number and oxidative activity of spleen Mø during Babesia infection, especially after treatment with CLM, may play an important role in host defense against murine babesiosis.

\section{REFERENCES}

1. Brinkmann, V., Kaufmann, E., Simon, M.M. and Fischer, H. 1984. Infect. Immun. 44: 743-746.

2. Gross, A., Geva, S. and Frankenburg, S. 1988. Exp. Parasitol. 65: 50-60.

3. Huber, W. G. 1977. pp. 959-960. In: Text Book of Veterinary
Pharmacology and Therapeutics, 4th ed. (Jones, M. L., Booth, N. H. and McDonald, L. E. eds.) The Iowa State University Press, Ames.

4. Mzembe, S. A., Lloyd, S. and Soulsby, E. J. 1984. Z. Parasitenkd. 70: 753-761.

5. Owhashi, M., Uemura, H., Kanbara, H. and Nawa, Y. 1997. Southeast Asian J. Trop. Med. Public Health 28: 757-763.

6. Prada, J., Neifer, S., Muller, S., Rudolph, R., Bienzle, U. and Kremsner, P.G. 1994. J. Pathol. 174: 57-62.

7. Rosenblatt-Bin, H., Klein, A. and Sredni, B. 1996. Parasitol. Immunol. 18: 297-306.

8. Ruebush, T. K., Rubin, R. H., Wolpow, E.R., Cassaday, P. B. and Schultz, M.G. 1979. Am. J. Trop. Med. Hyg. 28: 184-189.

9. Saeki, H. and Ishii, T. 1996. Vet. Parasitol. 61: 201-210.

10. Wijaya, A., Wulansari, R., Ano, H., Inokuma, H. and Makimura, S. 2000. J. Vet. Med. Sci. 62: 835-839.

11. Zivkovic, D., Speksnijder, J. E., Kuil, H. and Seinen, W. 1985. Vet. Immunol. Immunopathol. 9: 131-142. 